\title{
Türkiye İlaç Sektöründe Rekabetin Ölçülmesi
}

\author{
Dr. Öğr. Üyesi Hasan Hüseyin Yıldırım ${ }^{1 *}$ \\ Melih Mestanoğlu
}

Geliş tarihi: 28.08.2019

Kabul tarihi: 14.09.2019

\section{Atıf bilgisi:}

IBAD Sosyal Bilimler Dergisi

Sayı: Özel Sayı $\quad$ Sayfa: $340-352$

Yıl: 2019

This article was checked by iThenticate. Similarity Index $17 \%$.

\section{Balıkesir Üniversitesi, Türkiye, hhyildirim@balikesir.edu.tr. \\ ORCID ID 0000-0002-5840-8418}

2 Balıkesir Üniversitesi, Türkiye, melihmestanogluu@gmail.com, ORCID ID 0000-0002-4369-444X
ÖZ

Bireylerin en temel ihtiyaçlarından biri olan sağllğa yönelik üretim yapan ilaç sektörü, bireylerin yaşam kalitesini arttırmak için önemli ölçüde gelişme göstermiştir. Günümüzde ilaç endüstrisi yüksek oranda AR-GE maliyetlerine katlanan ve ekonomik olarak yüksek potansiyele sahip küresel bir endüstridir. Ekonominin diğer endüstri birimlerinde olduğu gibi yaşanan yoğun rekabet ortamı ilaç sektörü için de her geçen gün önemli hale gelmektedir. Bu çalışmada, Türkiye'de faaliyet gösteren yerli ve yabancı üretici firmalar belirlenerek firmalara ait elde edilen veriler ile endüstrinin rekabet ortamının belirlenmesi amaçlanmıştır. Ayrıca sektörde yer alan üretici ve tedarikçilerin sektördeki rekabet durumu ile ilgili düşüncelerini genel olarak değerlendirmek için frekans analizi ve her iki grubun rekabet durumu açısında aralarında fark olup olmadığını tespit etmek amacıyla Ttesti yapılmıştır. Sonuç olarak, üretici ve tedarikçiler arasında istatistiksel olarak anlamlı bir fark tespit edilmiştir.

Anahtar Kelimeler: Endüstri Analizi, İlaç Sektörü, Rekabet Analizi, Anket Çalışması, Türkiye 


\title{
Competitiveness in Turkey the Pharmaceutical Industry
}

\author{
Assist. Prof. Dr. Hasan Hüseyin Yıldırım ${ }^{1 *}$ \\ Melih Mestanoğlu ${ }^{2}$
}

First received: 28.08 .2019

Accepted: 14.09 .2019

\section{Citation:}

IBAD Journal of Social Sciences

Issue: Special Issue Pages: $340-352$

Year: 2019

This article was checked by iThenticate. Similarity Index $17 \%$.

$\begin{aligned} & \text { 1Balikesir University, Turkey, } \\ & \text { hhyildirim@balikesir.edu.tr, }\end{aligned}$
ORCID ID 0000-0002-5840-8418

ORCID ID 0000-0002-5840-8418

${ }^{2}$ Balikesir Üniversity, Turkey, melihmestanogluu@gmail.com,

ORCID ID 0000-0002-4369-444X

* Corresponding Author

\section{ABSTRACT}

One of the most basic needs of individuals, the pharmaceutical industry, which produces health-oriented products, has improved significantly to improve the quality of life of individuals. Nowadays, the pharmaceutical industry is a global industry with high economic potential and with high $\mathrm{R} \& \mathrm{D}$ costs. As in other industrial units of the economy, the intense competition environment is becoming more and more important for the pharmaceutical sector. In this study, domestic and foreign manufacturers operating in Turkey are determined and it is aimed to determine the competitive condition of the pharmaceutical industry with the obtained data from the companies. Also, a frequency analysis was carried out to generally evaluate the opinions of manufacturers and suppliers in the sector regarding the competitive situation. T-test was conducted to determine whether there was a difference between two groups in terms of the competitive situation. As a result, a statistically significant difference was found between the manufacturers and the suppliers.

Keywords: Industry Analysis, Pharmaceutical Industry, Competitive Analysis, Survey Analysis, Turkey. 


\section{INTRODUCTION}

In order to protect and sustain the health of people, which is the greatest treasure of the people, the structure of all institutions and organizations producing health-related goods and services is generally referred to as the health sector. Otherwise all health-oriented activities are called health services (Akin, 2007, p.6). Every passing day, the population of the world and the level of welfare are increasing. In addition, the elderly population with in the total population is rapidly increasing. All this has increased the demand for health services, and it has also led to the emergence of new needs.

The pharmaceutical industry is an important sector that affects human health due to its impact on the national and international economy and activities. The pharmaceutical industry develops and manufactures high value-added products as well as the value it adds to the extension of human life and to ensuring quality of life. It is considered as a strategic sector in terms of providing high-quality employment, high R \& D potential, technological and scientific contribution to the fields of medicine and pharmacy (Turkish Republic, Department of Science and Industry, 2015, p.9).

Manufacturers in the pharmaceutical industry; appear in the market in two ways as large-scale companies and small-scale firms. Products for international markets are provided by large-scale companies, while for regional or national markets products are provided by small-scale companies (OECD, 2003, p.27). Companies operating at global level have many patents and they are engaged in $\mathrm{R} \& \mathrm{D}$ investment while small-scale firms are the companies that manufacture drugs for which the patent protection period has expired or the products of companies operating at the global level under license.

\section{THE PHARMACEUTICAL INDUSTRY IN THE WORLD AND TURKEY}

According to the data of the Pharmaceutical Industry Employers' Association (IEIS, 2016), the volume of the world pharmaceutical market is \$1.1 trillion. The world pharmaceutical market is concentrated in three or four major markets. Mainly concentrated in three major markets such as the USA, the EU and Japan, consumption is largely met by production in developed countries. Respectively, the United States, China, Japan, Germany, France, Italy, UK, Brazil, Spain and Canada are the 10 largest markets in the world pharmaceutical industry. Turkey is ranked 16th in the rankings.

According to these data, at the end of 2016, the United States, which has a market volume of 462 billion dollars in the pharmaceutical sector, created a volume of more than the total of the 10 largest markets following it and is positioned as the leader of the sector. While Brazil and Britain have an equal market volume of $\$ 27$ billion, Turkey and Saudi Arabia have an equal market volume of $\$ 7$ billion.

Figure 1: World Pharmaceutical Market by Countries

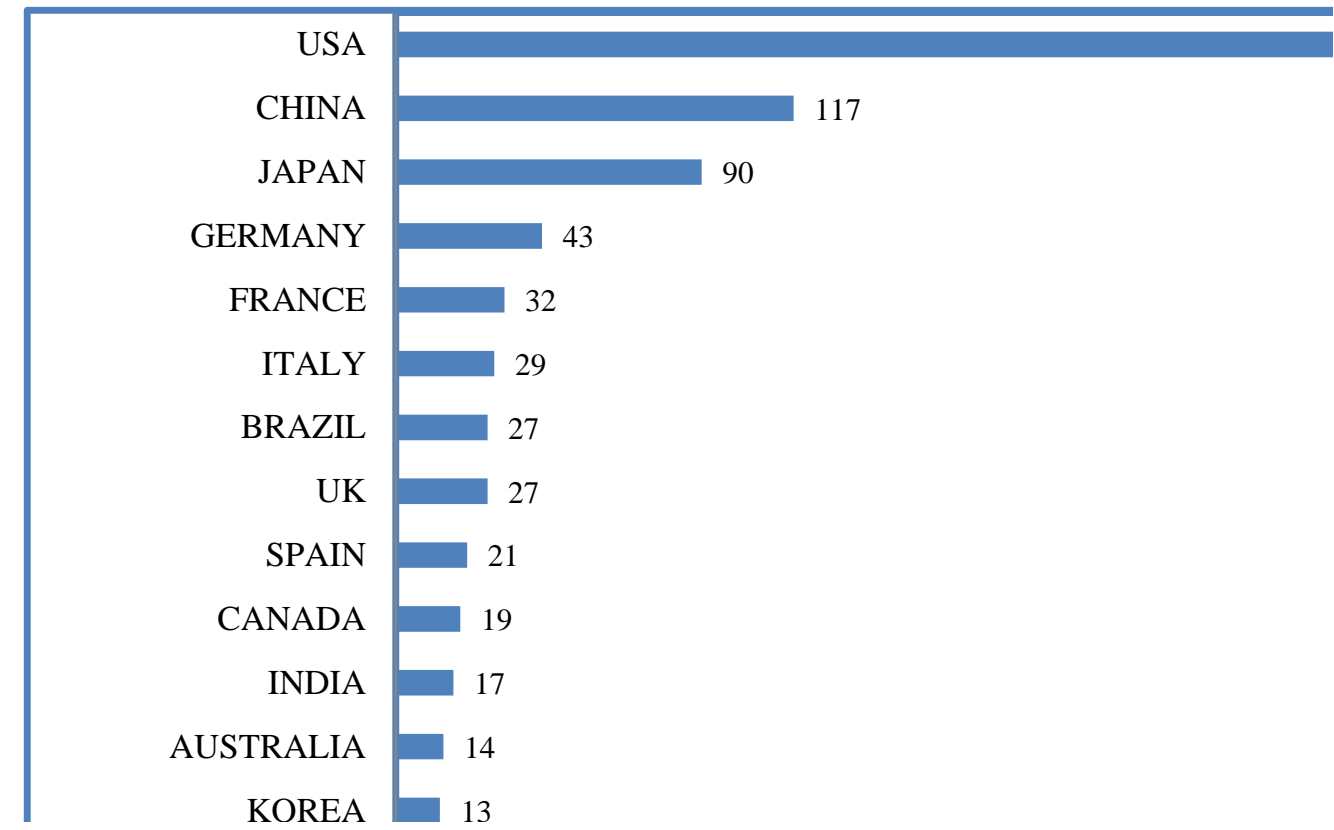


Figure 2: World Pharmaceutical Market by Region

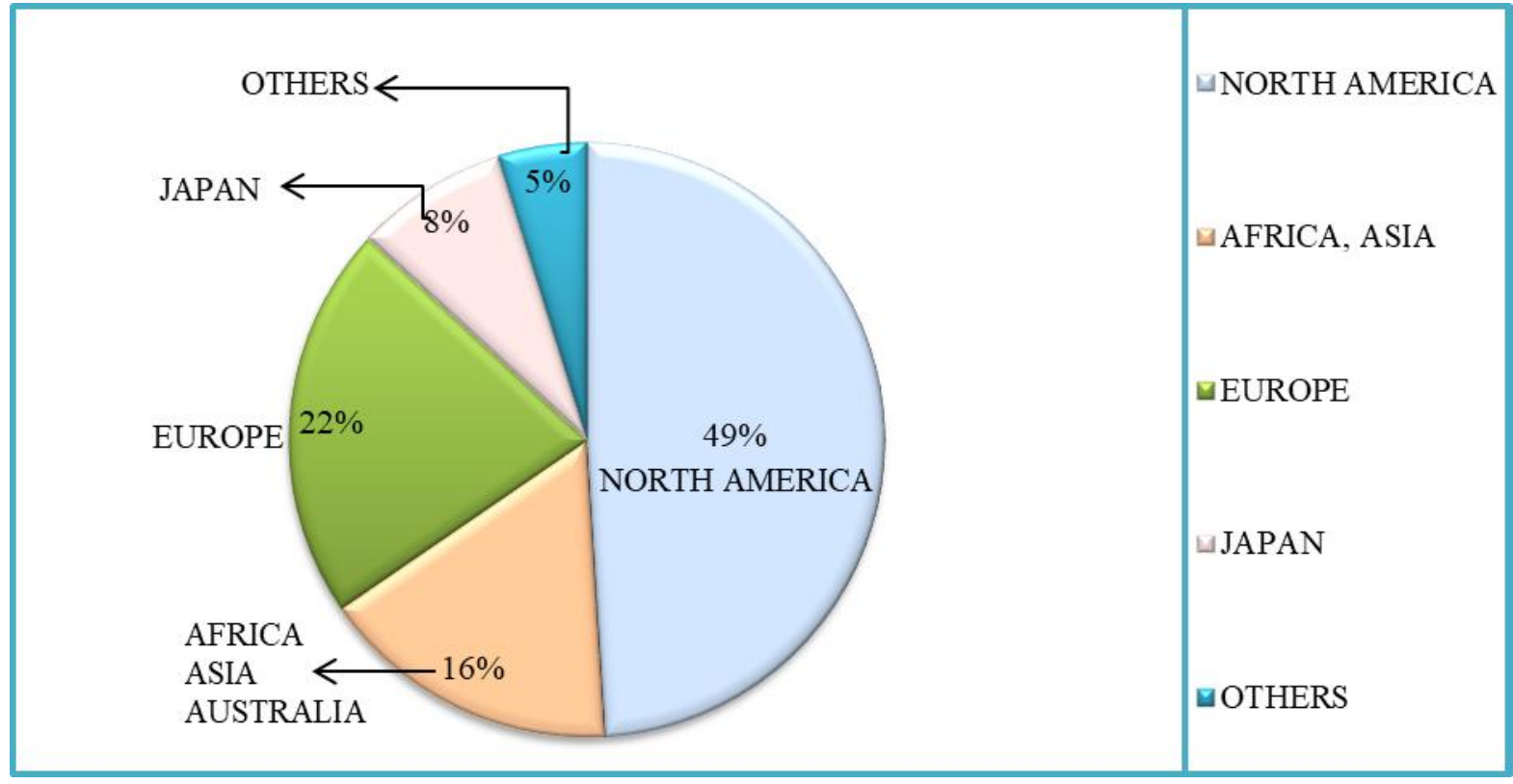

The market structure of the pharmaceutical sector is examined regionally in figure 2 . According to figure 2 , the USA and Canada constitute $49 \%$ of the world pharmaceutical markets as North American countries. Including China; Africa, Asia and Australia have a share of $16.4 \%$. Europe has a share of $21.5 \%$ and Japan has a share of $8.3 \%$.

The top 10 companies operating in the world pharmaceutical sector and their sales figures, net profits and employee numbers are listed in the table below. The data belong to Forbes 2017 Global 2000. These companies are also commercial leaders in the world pharmaceutical industry.

Table 1: World Pharmaceutical Companies (2017)

\begin{tabular}{|c|c|c|c|c|c|}
\hline COMPANIES & COUNTRIES & $\begin{array}{c}\text { SALES } \\
\text { (BILLION \$) }\end{array}$ & $\begin{array}{c}\text { NET PROFITS } \\
\text { (BILLION \$) }\end{array}$ & $\begin{array}{c}\text { MARKET } \\
\text { VALUE } \\
\text { (BILLION \$) }\end{array}$ & EMPLOYEES \\
\hline Allergan & Ireland & 15.9 & -4.1 & 80.1 & 16,700 \\
\hline Roche & Switzerland & 51.3 & 9.7 & 219.3 & 94,052 \\
\hline Pfizer & USA & 52.8 & 7.1 & 203.1 & 69,500 \\
\hline Novartis & Switzerland & 48.5 & 6.7 & 193.2 & 118,393 \\
\hline AbbVie & USA & 25.6 & 5.9 & 104.5 & 30,000 \\
\hline Sanofi & France & 37.4 & 5.2 & 116.1 & 106,859 \\
\hline Merck & USA & 39.6 & 3.9 & 173.3 & 68,000 \\
\hline AstraZeneca & United Kingdom & 23 & 3.7 & 75.2 & 59,700 \\
\hline McKesson & USA & 196.5 & 2 & 30.5 & 68,000 \\
\hline GlaxoSmithKline & United Kingdom & 37.6 & 1.2 & 99.8 & 99,300 \\
\hline
\end{tabular}

Among the top ten companies in the list of pharmaceutical companies, 4 companies, namely Pfizer, Merck, AbbVie and McKesson, are of US origin. The fact that the other six companies are of European origin, namely Switzerland (Novartis, Roche), France (Sanofi), Ireland (Allergan) and UK (AstraZeneca, GlaxoSmithKline), is a proof of the fact that the pharmaceutical market has an oligarchic market structure.

The use of advanced technology, high cost investments and long-term R \& D activities increase the importance of economies of scale in the pharmaceutical sector. This situation caused the dominance of multinational companies, which possess $95 \%$ of the world pharmaceutical market. Companies operating in the sector continue to grow with mergers and acquisitions, which have been intensively realized in recent years (Kaya, 2016, p.9). Another issue to be considered in the table is the number of people employed in the sector. The total number of employees of the top ten companies in the table is 
approximately 730,000 people. The total number of employees of 46 pharmaceutical companies included in the data published by Forbes 2017 Global 2000 is approximately 1,577 million. The top ten companies in the table constitute approximately $46.6 \%$ of the total employment in this sector.

Table 2: Top 10 Most Valuable Brands In The World (In The Pharmaceutical Industry)

\begin{tabular}{|c|c|c|c|c|}
\hline NAME OF COMPANY & ORIGIN & 2018 (MILLION \$) & 2019 (MILLION \$) & VARIANCE \\
\hline Roche & Switzerland & $\$ 6,413$ & $\$ 6,914$ & $+7.8 \%$ \\
\hline Bayer & Germany & $\$ 5,571$ & $\$ 6,209$ & $+11.5 \%$ \\
\hline Pfizer & United States & $\$ 4,098$ & $\$ 4,776$ & $+16.5 \%$ \\
\hline Abbott & United States & $\$ 3,700$ & $\$ 4,455$ & $+20.4 \%$ \\
\hline Merck & United States & $\$ 3.217$ & $\$ 4,141$ & $+28.7 \%$ \\
\hline Sanofi & France & $\$ 3,323$ & $\$ 3,384$ & $+1.8 \%$ \\
\hline Novartis & Switzerland & $\$ 3,580$ & $\$ 3.362$ & $-6.1 \%$ \\
\hline Celgene & United States & $\$ 3,133$ & $\$ 3,310$ & $+5.7 \%$ \\
\hline GlaxoSmithKlein & United Kingdom & $\$ 3,004$ & $\$ 3,286$ & $+9.4 \%$ \\
\hline AbbVie & United States & $\$ 2,483$ & $\$ 2,985$ & $+20.2 \%$ \\
\hline
\end{tabular}

The above table includes the top 10 most valuable companies in the world. These data were compiled by Brand Finance.

Roche has defended the title of the world's most valuable pharmaceutical brand, as its brand value increased $8 \%$ to US $\$ 6.9$ billion. Roche was able to stay ahead of second-ranked Bayer (brand value up $11 \%$ to US $\$ 6.2$ billion) although the gap between the two has narrowed slightly. Roche's brand value increase was driven by strong performance in the United States, where it benefited from a $14 \%$ growth in sales. Elsewhere, results were not so strong, particularly in Japan (sales steady) and Europe (sales down $8 \%$ ), where Roche is challenged by generic drugs undercutting sales (Brand Finance, Pharma10).

Merck (brand value up 29\% to US $\$ 4.1$ billion) is the year's biggest mover, with the brand achieving the fastest growth amongst the industry's top ten. Merck has jumped two places in the rankings, overtaking both Sanofi (brand value up 2\% to $\$ 3.4$ billion) and Novartis, to enter into the top 5. Merck's brand value bounced back strongly after it saw a decline last year, following a cyber-attack in June 2017 which both undermined customer confidence and reduced production of Gardasil 9 drugs. The resilience of the company in the face of challenging circumstances and ability to rebound strongly is testament to the strength of the brand (Brand Finance, Pharma10).

Table 3: Imports and Exports in the World Pharmaceutical Industry (Thousand \$)

\begin{tabular}{|c|c|c|c|c|}
\hline & 2013 & 2014 & 2015 & 2016 \\
\hline IMPORTS & $501,947,194$ & $530,497,936$ & $516,295,529$ & $525,513,690$ \\
\hline EXPORTS & $488,583,562$ & $512,553,025$ & $455,746,421$ & $493,910,837$ \\
\hline
\end{tabular}

The table above contains the import and export data of total pharmaceutical products in the world. In 2016, total trade volume in the world was 15.9 trillion dollars in exports and 16 trillion dollars in imports, constituting a total of $\$ 31.9$ trillion. As of 2016, the total trade volume in the pharmaceutical market was approximately 1 trillion dollars. This figure constitutes approximately $3.1 \%$ of the total goods trade volume. This situation once again emphasizes the importance of the health sector and the market size. When we look at the years, it is possible to say that the import and export figures in the sector have increased significantly compared to the previous years. Pharmaceutical imports, which were $\$ 501.9$ billion in 2013, increased to 525.5 billion dollars in 2016 and increased by $4.7 \%$. Pharmaceutical exports, which amounted to 488.5 billion dollars in 2013, increased to $\$ 493.9$ billion in 2016 and increased by $1.1 \%$. Factors such as the length of life expectancy, changing demographic structures of 
societies, different disorders, and the social state phenomenon have led to the development of this sector day by day and the growth of the market volume.

\subsection{Pharmaceutical Industry in Turkey}

The history of Turkey's pharmaceutical industry is based on the pre-republic period. In the pre-republic period, ready-made pharmaceuticals began to be manufactured in pharmacies. In 1915, the number of ready-made drugs reached 30, and other pharmaceutical products were imported. After the proclamation of the Republic, with the Law No. 1262 enacted in 1928, state control was established in the importation and production of pharmaceuticals, and a competitive environment was established between imported drugs and domestic medicine. In 1930, the laboratory period began, and after 1952, foreign and domestic factories were established, industrialization started and the industry showed a rapid development. In addition, foreign direct investments made in this period provided infrastructure for the development of the sector. The Good Manufacturing Practices determined by the World Health Organization between 1973-1990 and the introduction of various international standards aimed to attract more investors. The pharmaceutical sector that grew rapidly between 1990 and 2003 experienced various problems such as pricing and taxation. Pricing is based on the prices of 5 EU countries (Spain, France, Italy, Portugal, Greece) determined by the Ministry of Health. Then, in 2015, a number of adjustments were made to the reference price system.

Turkey's pharmaceutical sector has considerable export potential in terms of the quantity and range of products and is one of the sectors with high added value. The Turkish pharmaceutical sector, apart from products that require special production technology (biotechnology, etc.), can produce all kinds of products, and it has reached a technological level comparable with the EU countries. It has strengthened its technological infrastructure by making the necessary investments within the framework of the Good Manufacturing Practices (GMP) which were determined by the World Health Organization and came into force in 1984 in our country (Turkish Republic, Department of Science and Industry, 2016, p.8).

Turkey's pharmaceutical market, with a total increase of $16.5 \%$ in the first three months of 2017, reached 6.15 billion TL to hospitals and pharmacies. The number of boxes, however, decreased by $0.3 \%$ to 0.61 billion boxes. This reduction in the box volume is due to a $2.5 \%$ decrease in the sales of pharmaceuticals in hospitals. When the average price level, which is calculated by dividing the total market size by the box volume, is examined, it is seen that the average price, which was $8.6 \mathrm{TL}$ in the first 3 months of 2016, increased by $17 \%$ in 2017 to 10 TL (IEIS, 2017).

Drug manufacturers, pharmaceutical warehouses and pharmacies are important actors in the sector in Turkey. The drug reaches the final consumer through production, distribution and sales channels. Pharmaceutical manufacturers are companies that manufacture or import in the sector. Drug warehouses are intermediaries who take the drug from the producers and deliver it to pharmacies, acting as a distribution channel. Pharmacies sell the drugs they take from the warehouse to the consumer.

\section{Table 4: The Structure of the Pharmaceutical Sector in Turkey}

\begin{tabular}{|l|c|}
\hline Manufacturing Companies & 71 \\
\hline Local & 56 \\
\hline Foreign & 15 \\
\hline Raw Material Plants & 12 \\
\hline Local & 6 \\
\hline Foreign & 6 \\
\hline Pharmaceutical Warehouses & 516 \\
\hline Representative Pharmaceutical Warehouses & 85 \\
\hline Pharmacies (estimated) & 24,150 \\
\hline
\end{tabular}

There are a total of 71 producers in the sector, 56 of which are domestic. Foreign firms produce medicine by contract or under license in Turkey. In addition, there are a large number of importer companies that supply medicines from abroad through the licensing process and supply them to the domestic market. When these companies are included, there are a total of 332 firms in the sector. Considering the number of companies supplying products to the market, it is seen that the Turkish 
pharmaceutical industry has a rather fragmented structure in contrast to the global structure (Kaya, 2016, p.16).

A drug produced by the manufacturer and supplied to the market by taking out a patent is called a reference / innovative drug. Equivalent medicines are drugs prepared in the same forms as reference drugs by manufacturing firms other than the developing company. While reference / innovative drug production or imports are made in Turkey, equivalent / generic drugs constitute the main activity areas of the industry. In addition, drug research is not more likely to find a new molecule or develop a new drug and the molecules are made by developing different dosage forms with 2-3 combinations. As of March 2016, the number of clinical studies was 2,108 in Turkey. Turkey was, in terms of the number of clinical trials, 30th in the world, and ranked 17th in Europe (Turkish Republic, Department of Science and Industry, 2016, p.14).

\section{Figure 3: Pharmaceutical Sector Employment in Turkey}

\begin{tabular}{|c|c|c|c|c|c|c|c|}
\hline & 32 & 31.49 & 31.37 & & & & 31.46 \\
\hline & 31.5 & & & & & 30.9 & \\
\hline$\frac{0}{2}$ & 31 & & & & & & \\
\hline$\overline{8}$ & 30.5 & & & & & & \\
\hline 岂 & 30 & & & & 29.62 & & \\
\hline 莺 & 29.5 & & & 29.29 & & & \\
\hline 色 & 29 & & & & & & \\
\hline & 28.5 & & & & & & \\
\hline & & 2010 & 2011 & 2012 & 2013 & 2014 & 2015 \\
\hline
\end{tabular}

According to the Pharmaceutical Industry's IEIS Report 2016 for Turkey; in 2015, approximately 31,500 people worked in the pharmaceutical sector. The table above summarizes the change in employment data per year in the sector. Price-oriented policies implemented during the global budget period inevitably affect the sector's employment data. As a matter of fact, the number of people in the sector has been seriously eroded since 2010. In 2015, the sector reached the same human resources level as in 2010 (IEIS, 2016). In addition, more than 50\% of the employment in the sector had a higher education level. The majority of the current employment is in areas such as pricing, licensing and marketing rather than production.

Table 5: Companies operating in the pharmaceutical sector in Turkey (2016)

\begin{tabular}{|c|c|c|c|c|c|c|}
\hline Name of the Company & $\begin{array}{l}\text { Registered } \\
\text { Institution }\end{array}$ & $\begin{array}{l}\text { General } \\
\text { Ranking }\end{array}$ & $\begin{array}{l}\text { Private Sector } \\
\text { Ranking }\end{array}$ & Net Profit & $\begin{array}{c}\text { Exports } \\
\text { (Thousand } \\
\$)\end{array}$ & $\begin{array}{l}\text { Number of } \\
\text { Employees }\end{array}$ \\
\hline Abdi İbrahim İlaç San. ve Tic. A.Ş & Istanbul & 125 & 117 & $832,747,305$ & 34,542 & 2,275 \\
\hline Deva Holding A.Ş & Istanbul & 195 & 187 & $589,429,456$ & 13,840 & 1,850 \\
\hline Koçak Farma İlaç ve Kimya Sanayi A.Ş & Istanbul & 222 & 213 & $530,899,204$ & - & 1500 \\
\hline Nobel İlaç San. ve Tic. A.Ş & Istanbul & 296 & 287 & $421,114,527$ & 56,712 & 1,156 \\
\hline SantaFarma İlaç Sanayi A.Ş & Istanbul & 451 & 440 & $266,952,592$ & 1,914 & 927 \\
\hline İ.E. Ulagay İlaç Sanayi T.A.Ş & Istanbul & 600 & 598 & $204,773,866$ & - & - \\
\hline Ali Raif İlaç Sanayi A.Ş & Istanbul & 602 & 600 & $204,306,617$ & - & - \\
\hline Biofarma İlaç San. ve Tic. A.Ş & Istanbul & 812 & 809 & $145,640,546$ & 4,174 & 587 \\
\hline Adeka İlaç San. ve Tic. A.Ş & Samsun & 838 & 835 & $139,551,365$ & - & 482 \\
\hline $\begin{array}{l}\text { TMO Genel Müdürlüğü Afyon } \\
\text { Alkaloidleri Fabrikası }\end{array}$ & Public & 1000 & - & $103,498,573$ & - & 297 \\
\hline
\end{tabular}

Table 5 contains the data of the largest and the second largest 500 industrial companies prepared by the Istanbul Chamber of Industry (ISO) in 2016. In the ranking, sales from production were taken into consideration. According to the data; there were 10 pharmaceutical manufacturers in the large list of 500 industrial establishments determined by the ISO. Nine of these ten drug manufacturers are privately owned, while one of them is publicly owned. Abdi İbrahim İlaç ve San. A.Ş. is quite superior in terms of net sales and number of employees compared to other manufacturers. The net sales of these ten drug manufacturers, shown in Table 4, from total production in 2016 amounted to approximately 3.6 billion TL. 
When we look at the employment data, although the number of employees of two producers in the table could not be obtained, the total number of employees of the other 8 manufacturers was calculated as 9,074 .

Except for the manufacturers given in the table, all of the world's 10 largest pharmaceutical producers are active in the Turkish market. Also Pfizer, Sanofi and Novartis are companies that have established production facilities in Turkey. Glaxo Smith Kline has plans to set up a R \& D and production plant in Turkey. It is observed that some global companies have located Turkey as a regional center in their organizational structure in the areas of production or sales (Kaya, 2016, p.17)

Table 6: Total Imports and Exports in Turkey (thousand \$)

\begin{tabular}{|c|c|c|c|c|c|}
\hline Years & $\mathbf{2 0 1 3}$ & $\mathbf{2 0 1 4}$ & $\mathbf{2 0 1 5}$ & $\mathbf{2 0 1 6}$ & $\mathbf{2 0 1 7}$ \\
\hline Imports & $251,661,250$ & $242,177,117$ & $207,206,509$ & $198,618,235$ & $233,791,662$ \\
\hline Exports & $151,802,637$ & $157,610,158$ & $143,850,376$ & $142,529,584$ & $157,055,371$ \\
\hline Trade Balance & $-99,858,613$ & $-84,566,959$ & $-63,356,133$ & $-56,088,651$ & $-76,736,291$ \\
\hline
\end{tabular}

Table 6 includes Turkey's total import and export data between 2013-2017. These data include only import and export data. Total service import and export data are not included.

Table 7: Turkey's Imports and Exports in the Pharmaceutical Sector (thousand \$)

\begin{tabular}{|c|c|c|c|c|c|}
\hline Years & $\mathbf{2 0 1 3}$ & $\mathbf{2 0 1 4}$ & $\mathbf{2 0 1 5}$ & $\mathbf{2 0 1 6}$ & $\mathbf{2 0 1 7}$ \\
\hline Imports & $4,151,045$ & $4,428,199$ & $4,296,440$ & $4,217,114$ & $4,449,099$ \\
\hline Exports & 754,085 & 805,583 & 878,149 & 826,774 & 875,480 \\
\hline
\end{tabular}

Table 7 contains import and export values of Turkey in the pharmaceutical sector. Import and export values include the data between 2013-2017. When we look at the data, imports increased by $7.1 \%$ and exports by $16 \%$ between 2013 and 2017. According to the 2017 Trade Map data, the total volume of the pharmaceutical industry in Turkey was 5.3 billion dollars. According to these data, Turkey's pharmaceutical exports constituted approximately $0.16 \%$ of world pharmaceutical exports. When Turkey is examined overall, total trading volume showed a growth of $14.5 \%$ in 2017 compared to the previous year, and when viewed only in terms of exports it showed a growth of $10.1 \%$. Total trade volume amounted to 390.8 billion TL, which included 233.8 billion TL in imports, and exports of 157 billion TL. In the same period, Turkey's pharmaceutical exports showed a growth rate of $5.8 \%$ compared to the previous year and also made a contribution of $0.55 \%$ to total product exports.

\section{LITERATURE REVIEW}

There are not many related studies or similar studies in the literature review. In this study, therefore, it was aimed to eliminate the deficiency in the literature and to contribute to future studies.

Scherer and Ross (1990), in their study on industrial market and structure and economic performance, concluded that the first market manufacturers in the pharmaceutical industry did not experience any loss in the market although they offered high prices.

Towse (1995) stated in his study that public policy actions have a significant impact on the speed of technological progress in the pharmaceutical sector.

Levy (1999) examined the product price, competitive strategies and concentration level in the pharmaceutical industry. It was determined that the pharmaceutical sector was heading towards monopolization.

In a study by Roberts (1999), the relationship between innovation, competition and high profitability in the US pharmaceutical industry was investigated. Findings showed a positive relationship between innovation tendency and high profitability, and increased concentration was determined.

Akbolat and Iş1k (2012) conducted a study on the competitiveness strategies and performances in hospitals using the 2007 statistics of the Ministry of Health and a questionnaire applied to 165 people. It was determined that all hospitals follow differentiation, focusing and total cost leadership strategies and that the hospitals following any strategy have higher performances than the hospitals that do not follow 
any strategy. According to the chi-square and ANOVA test results, there was no statistically significant difference between the hospitals following one of these competition strategies.

Kaynak (2016), analyzed the concentration level and competitive structure of the Turkish pharmaceutical industry with the n-firm concentration ratio (CRn) and Herfindahl Hirschman index (HHI). According to the findings, it was observed that the concentration in the Turkish pharmaceutical sector was low compared to CR4 and CR8. However, it was observed that the concentration of domestic firms in the Turkish-origin pharmaceutical sector and foreign companies in the foreign-origin pharmaceutical sector were dominated by a high and oligopolistic market structure. According to the HH index, the concentration ratio in both the local and imported pharmaceutical sectors was not high.

Doğan et al. (2017) conducted a survey of 224 people covering 2 public and 2 private hospitals and employees in Kahramanmaraş and investigated the relationship between competition strategies and quality levels. According to the study of competition strategies and performances in hospitals, using regression analysis, competitive strategies including cost leadership, differentiation and focus had a significant positive effect on all quality dimensions. As a result of the correlation analysis, statistically significant relationships were found.

\section{PURPOSE AND METHOD OF RESEARCH}

In this study, domestic and foreign manufacturers operating in Turkey are determined and it is aimed to determine the competitive environment of the industry with the data obtained from the companies. In addition, frequency analysis was conducted to evaluate the opinions of the manufacturers and suppliers in the sector regarding the competition situation in the sector. In order to determine whether there was a difference between the two groups in terms of competition, a T-test was performed. A statistically significant difference was found between producers and suppliers.

The questionnaire form of the research consists of 12 statements in total. The first statement was prepared with two options to identify the respondent. We used a 5-point Likert scale to measure ten statements in the questionnaire, and a 7-point Likert scale to measure one statement.

The SPSS 20 package program was used to analyze the data. Firstly, factor analysis was done. Then, a validity and reliability test was applied to measure the accuracy and consistency of the data. In the results, the factor structure and Cronbach's alpha value and Bartlett's sphericity test results showed good results. Frequency analysis and T-test were applied to the data obtained after these analyses. The results of the analysis are given in detail in the findings of the research.

\subsection{Research Data}

The universe of this research consists of 94 manufacturers, pharmaceutical wholesalers and pharmacists operating in the Marmara Region. When we were doing the survey it was impossible to reach all the people. Therefore, the questionnaire was conducted on 134 people who could be reached by the guided sampling method within a population. 11 of the questionnaire forms were not included in the study due to lack of information. So, 123 questionnaires were used for the research. The study was conducted between 25th February and 4th March 2018 by face-to-face questionnaire.

\subsection{Findings of the Research}

\section{Table 8: Factor Analysis}

KMO and Bartlett's Test

\begin{tabular}{|c|c|}
\hline $\begin{array}{ll}\text { Kaiser-Meyer-Olkin Measure of Sampling Adequacy. } \\
& \text { Approx. Chi-Square } \\
\text { Bartlett's Test of Sphericity } & \text { df } \\
& \text { Sig. }\end{array}$ & $\begin{array}{c}0.831 \\
296.585 \\
28 \\
0.000\end{array}$ \\
\hline
\end{tabular}

Examining the data obtained from the sample, the KMO value was found to be 0.831 . This shows that the data are valid. When we look at Bartlett's sphericity test results Sig. $(p<0.05)$ was found to be less than 0.05 and so was found to be significant. Cronbach's alpha value was found to be 0.82 . The results of the factor analysis conducted according to these results are shown in the table below. 
Table 9: Factor Analysis Results Table

\begin{tabular}{|c|c|c|}
\hline \multirow[t]{2}{*}{ Scale Statement } & \multicolumn{2}{|c|}{ Results of Factor Analysis } \\
\hline & 1 & 2 \\
\hline $\begin{array}{c}\text { S5 } \\
\text { S7 } \\
\text { S2 } \\
\text { S4 } \\
\text { S11 } \\
\text { S10 } \\
\text { S8 } \\
\text { S3 }\end{array}$ & $\begin{array}{l}0.764 \\
0.743 \\
0.741 \\
0.661\end{array}$ & $\begin{array}{l}0.843 \\
0.767 \\
0.669 \\
0.574\end{array}$ \\
\hline
\end{tabular}

The ten statements in the questionnaire were analyzed by exploratory factor analysis. Two of these ten statements were excluded from the analysis because they did not have sufficient factor loadings. When the analysis was repeated, the desired results were reached. Two factors were obtained from these eight statements. These two factors explain $59.1 \%$ of the total variance.

Table 10: Frequency Analysis

\begin{tabular}{|c|c|c|}
\hline & Number of People & Percentage $(\%)$ \\
\hline Manufacturers & 72 & 58.5 \\
\hline $\begin{array}{c}\text { Suppliers } \\
\text { (Pharmacies - Pharmaceutical Warehouses) }\end{array}$ & 51 & 41.5 \\
\hline Total & 123 & 100 \\
\hline
\end{tabular}

123 people participated in the survey. $58.5 \%$ of the respondents were answered by the Manufacturers, and $41.5 \%$ of them were pharmacists and pharmaceutical warehouse staff, who are named the Suppliers.

\section{Table 11: Results of Survey Form Used in the Study}

\begin{tabular}{|c|c|c|c|c|c|c|c|}
\hline & & 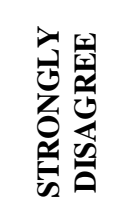 & 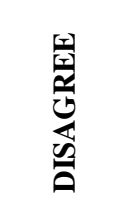 & 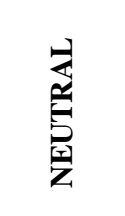 & 㕿 & 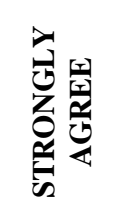 & 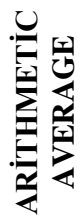 \\
\hline \multirow{2}{*}{ Q2: } & \multirow{2}{*}{$\begin{array}{l}\text { Turkey's production capacity in the } \\
\text { pharmaceutical sector has international } \\
\text { standards. }\end{array}$} & 12 & 27 & 15 & 47 & 22 & \multirow{2}{*}{3.330} \\
\hline & & $(9.8 \%)$ & $(22.0 \%)$ & $(12.2 \%)$ & $(38.2 \%)$ & $(17.9 \%)$ & \\
\hline \multirow{2}{*}{ Q3: } & \multirow{2}{*}{$\begin{array}{l}\text { The labor force in Turkey's pharmaceutical } \\
\text { industry has sufficient qualified personnel. }\end{array}$} & 1 & 34 & 36 & 44 & 8 & \multirow{2}{*}{3.198} \\
\hline & & $(0.8 \%)$ & $(27.6 \%)$ & $(29.2 \%)$ & $(35.8 \%)$ & $(6.5 \%)$ & \\
\hline \multirow{2}{*}{ Q4: } & \multirow{2}{*}{$\begin{array}{l}\text { Turkey has a strong competitive environment } \\
\text { in the pharmaceutical industry. }\end{array}$} & 6 & 9 & 9 & 54 & 45 & \multirow{2}{*}{4.000} \\
\hline & & $(4.9 \%)$ & $(7.3 \%)$ & $(7.3 \%)$ & $(43.9 \%)$ & $(36.6 \%)$ & \\
\hline \multirow{2}{*}{ Q5: } & \multirow{2}{*}{$\begin{array}{l}\text { Turkey's pharmaceutical industry has a strong } \\
\text { growth trend. }\end{array}$} & 1 & 8 & 20 & 62 & 23 & \multirow{2}{*}{3.647} \\
\hline & & $(8.1 \%)$ & $(6.5 \%)$ & $(16.3 \%)$ & $(50.4 \%)$ & $(18.7 \%)$ & \\
\hline \multirow{2}{*}{ Q6: } & \multirow{2}{*}{$\begin{array}{l}\mathrm{R} \& \mathrm{D} \text { expenditure in Turkey's pharmaceutical } \\
\text { industry is inadequate. }\end{array}$} & 4 & 11 & 15 & 46 & 47 & \multirow{2}{*}{3.983} \\
\hline & & $(3.3 \%)$ & $(8.9 \%)$ & $(12.2 \%)$ & $(37.4 \%)$ & $(38.2 \%)$ & \\
\hline \multirow{2}{*}{ Q7: } & \multirow{2}{*}{$\begin{array}{l}\text { The regulations of the public sector affect the } \\
\text { development of the pharmaceutical industry } \\
\text { sector positively. }\end{array}$} & 24 & 27 & 29 & 38 & 5 & \multirow{2}{*}{2.778} \\
\hline & & $(19.5 \%)$ & $(22.0 \%)$ & $(23.6 \%)$ & $(30.9 \%)$ & $(4.1 \%)$ & \\
\hline \multirow{2}{*}{ Q8: } & \multirow{2}{*}{$\begin{array}{l}\text { Distribution channels in the pharmaceutical } \\
\text { sector are sufficient. }\end{array}$} & 8 & 26 & 29 & 47 & 13 & \multirow{2}{*}{3.258} \\
\hline & & $(6.5 \%)$ & $(21.1 \%)$ & $(23.5 \%)$ & $(38.2 \%)$ & $(10.6 \%)$ & \\
\hline \multirow{2}{*}{ Q9: } & \multirow{2}{*}{$\begin{array}{l}\text { The raw material supply needed in the } \\
\text { pharmaceutical industry is not sufficient. }\end{array}$} & 3 & 25 & 19 & 49 & 27 & \multirow{2}{*}{3.585} \\
\hline & & $(2.4 \%)$ & $(20.3 \%)$ & $(15.4 \%)$ & $(39.8 \%)$ & $(22.0 \%)$ & \\
\hline \multirow{2}{*}{ Q10: } & \multirow{2}{*}{$\begin{array}{l}\text { Turkey's pharmaceutical industry has the } \\
\text { strength to meet the production needs of the } \\
\text { domestic market. }\end{array}$} & 18 & 30 & 26 & 36 & 13 & \multirow{2}{*}{2.967} \\
\hline & & $(14.6 \%)$ & $(24.4 \%)$ & $(21.1 \%)$ & $(29.3 \%)$ & $(10.6 \%)$ & \\
\hline \multirow{2}{*}{ Q11: } & \multirow{2}{*}{$\begin{array}{l}\text { The variety of products in Turkey's } \\
\text { pharmaceutical industry production has } \\
\text { sufficient levels. }\end{array}$} & 13 & 40 & 20 & 36 & 14 & \multirow{2}{*}{2.989} \\
\hline & & $(10.6 \%)$ & $(32.5 \%)$ & $(16.3 \%)$ & $(29.3 \%)$ & $(11.4 \%)$ & \\
\hline
\end{tabular}

According to the results of the survey conducted on 123 people, the frequency distributions are as follows: the proportion of people who thought that Turkey's pharmaceutical industry had a production 
capacity up to international standards $(\mathrm{Q} 2)$ and that there were enough qualified staff $(\mathrm{Q} 3)$ was found to be greater than $50 \%$. $80.5 \%$ of the sample group stated that there was strong competition in the pharmaceutical sector in Turkey (Q4). According to the IEIS report, the number of firms was 441 in the sector in 2010, and then it increased to 496 in 2016. This situation can be said to be one of the factors that support the competitive environment. The proportion of people who thought that Turkey's pharmaceutical industry had a strong growth trend (Q5) was determined to be $69.1 \%$. In the sources, Turkey's pharmaceutical market had reached 20.67 billion TL in 2016 with 16.5\% growth in the total hospital and pharmacy channel (IEIS). At the same time, it was determined that the share allocated to R \& D was insufficient (Q6) and that public restrictions had a negative effect on the pharmaceutical industry sector (Q7). The share allocated to R \& D in the pharmaceutical sector, where competition is intense, is insufficient. In addition, the restrictions made by the government affect the strength of competition in the pharmaceutical sector in Turkey negatively. While most of the sampling group believed that distribution channels were adequate in the pharmaceutical sector $(\mathrm{Q} 8)$, they believed that the required raw material supply was not sufficient (Q9). The number of people who thought that Turkey's domestic production in the pharmaceutical sector had the power to meet the needs of the market, was close to the number of people who disagreed (Q10) This situation was the same in Q11.

Table 12: 7-Point Likert Result

\begin{tabular}{|c|c|c|c|}
\hline \multicolumn{2}{|c|}{ Q12: Profit margins in Turkey's pharmaceutical industry are sufficient. } \\
\hline & Total & Producers & Suppliers \\
\hline Barely & $15(12.2 \%)$ & $4(5.57 \%)$ & $11(21.56 \%)$ \\
\hline Very low & $18(14.6 \%)$ & $4(5.57 \%)$ & $14(27.45 \%)$ \\
\hline Low & $39(31.7 \%)$ & $22(30.51 \%)$ & $17(33.34 \%)$ \\
\hline Sufficient & $31(25.2 \%)$ & $25(34.73 \%)$ & $6(11.76 \%)$ \\
\hline More than sufficient & $15(12.2 \%)$ & $13(18.06 \%)$ & $2(3.93 \%)$ \\
\hline Much more than sufficient & $4(3.3 \%)$ & $3(4.17 \%)$ & $0(1.96 \%)$ \\
\hline Excessively sufficient & $1(0.8 \%)$ & $1(1.39 \%)$ & $0(0 \%)$ \\
\hline Arithmetic Average & $\mathbf{3 . 2 3 5}$ & & \\
\hline
\end{tabular}

According to the findings, $58.5 \%$ of the groups said that Turkey did not have a sufficient level of profit margins in the pharmaceutical sector, while $16.3 \%$ stated that profit margins in this sector were more than sufficient. $25.2 \%$ of the groups stated that the profit margins were sufficient. As a result, based on these data, it can be said that profit margins in the drug industry in Turkey are not at a sufficient level.

Table 13: T-Test

\begin{tabular}{|c|c|c|c|c|c|c|c|c|}
\hline & & \multicolumn{2}{|c|}{$\begin{array}{c}\text { Levene's Test for } \\
\text { Equality of } \\
\text { Variances }\end{array}$} & \multicolumn{5}{|c|}{ t-test for Equality of Means } \\
\hline & & $\mathrm{F}$ & Sig. & $\mathrm{t}$ & df & $\begin{array}{l}\text { Sig. (2- } \\
\text { tailed) }\end{array}$ & $\begin{array}{c}\text { Mean } \\
\text { Difference }\end{array}$ & $\begin{array}{l}\text { Std. Error } \\
\text { Difference }\end{array}$ \\
\hline \multirow{2}{*}{$\begin{array}{l}\text { Competition } \\
\text { status }\end{array}$} & $\begin{array}{l}\text { Equal variances } \\
\text { assumed }\end{array}$ & \multirow[t]{2}{*}{6.054} & \multirow[t]{2}{*}{0.015} & 2.108 & 121 & 0.037 & 0.31368 & 0.14883 \\
\hline & $\begin{array}{l}\text { Equal variances } \\
\text { not assumed }\end{array}$ & & & 2.004 & 87.145 & 0.048 & 0.31368 & 0.15650 \\
\hline
\end{tabular}

In order to test whether there was a difference in terms of competition between manufacturers and suppliers, independent two sample t-test was applied by including statements Q2, Q4, Q5, Q7, Q10, Q11, which are considered to be similar.

In the results of the test, it was found that the value of $t$ was 2.004 and the value of Sig. was 0.048 . Accordingly, the competitiveness felt by the manufacturing companies was 0.3136 more than the competitiveness felt by the suppliers. This difference is statistically significant (0.048). 


\section{CONCLUSION AND RECOMMENDATIONS}

The pharmaceutical sector, which plays an important role in the health and quality of life of individuals, is a sector with a strategic importance which increases the competitiveness of countries at the international level and provides a technological and scientific contribution to the fields of medicine and pharmacy in countries. In addition, the pharmaceutical sector is among the priority sectors in developed or developing countries because of the production or development of high value-added products, the creation of employment by highly educated people in the sector and the high R \& D potential.

In this study, the concepts of health and medicine were mentioned. Then, the state of the pharmaceutical industry in the world and Turkey, sectoral structure, companies located in the pharmaceuticals sector and their market shares were taken up. Later, manufacturers located in the pharmaceutical industry in Turkey and their opinions about the state of competition in the supply sector were given in order to assess the overall survey results obtained.

The T-test was performed in order to determine the difference between the two groups. According to the results of the T-test, a statistically significant difference was found between the competition status of the two groups. A difference of 0.3136 between the manufacturers and the suppliers was determined.

The fact that one of the random sampling methods is not used in this study constitutes a limitation of the study. In the study, because of its advantage in terms of time and cost, the guided sampling method was used. The data of the study were obtained only in the Marmara region and with a non-random sampling method. The application of the study to other regions in order to be more comprehensive will be more generative in terms of study results.

Acknowledgement: This study was presented at 1. International Congress of Political, Economic and Financial Analysis in 2018 at Adnan Menderes University in Aydın, Turkey.

\section{REFERENCES}

Adrian, T. and David, H. (1995). Industrial policy and the pharmaceutical industry. London: Office of Health Economics.

Akbolat, M. and Ișık, O. (2012). Hastanelerde rekabet stratejileri ve performans. Atatürk Üniversitesi Sosyal Bilimler Enstitüsü Dergisi 16(1), 401-424.

Akın, C.S. (2007). Sağllk ve sağllk harcamalarının ekonomik büyüme üzerine etkisi: Türkiye’de sağllk sektörü harcamaları. Unpublished Master Thesis, Çukurova University, Adana.

Brand Finance (2019). The annual report on the most valuable and strongest pharma brands. From www.brandfinance.com, on 12/07/2019.

Doğan, İ.F., Bakan, İ. and Hayva, S. (2017). Sağlık sektörünün temel aktörleri olan hastanelerde rekabet stratejilerinin kaliteye etkisi. Elektronik Sosyal Bilimler Dergisi, 16(62), 817-835.

Forbes (2017). The world's biggest public companies. From www.forbes.com, on 08/04/2018.

İEİS (2016). Dünya ilaç pazarı, From www.ieis.org.tr, on 09/04/2018.

İEIS (2017). Türkiye ilaç pazarı. From www.ieis.org.tr, on 09/04/2018.

ISO (2016). ISO İlk ve ikinci 500 sanayi kuruluşları. From www.iso500.org.tr, on12/04/2018.

Karakoç, H. D. (2005). Illaç sektöründe fiyat rekabeti. Ankara: Rekabet Kurumu.

Kaynak, S. (2016). Türk ilaç sektörünün rekabet yapısı ve yoğunlaşma analizi. Çankırı Karatekin Üniversitesi İktisadi ve İdari Bilimler Fakültesi Dergisi, 6(2), 49-66.

KPMG (2018). Sektörel bakış (ilaç sektörü). From www.kpmg/tr, on 10/04/2018. 
Levy, R. (1999). The pharmaceutical industry: A discussion of competitive and antirust issues in an environment of change. Bureau of Economics Staff Report (Federal Trade Commission).

OECD (2012). Regulatory reform review of Germany, Review of Germany.

Sarsın Kaya, D. (2016). İlaç sektörü. İstanbul: İş Bankası. From www.ekonomi.isbank.com.tr, on $10 / 04 / 2018$.

Sektörel rapor ve analizler: ilaç sektörü raporu (2016). Ankara: Turkish Republic, Department of Science and Industry.

Scherer, F.M. and D. Ross (1990). Industrial market structure and economic performance. Boston: Houghton Mifflin Co.

Bilim Sanayi ve Teknoloji Bakanlığı (2015). Strateji belgesi ve eylem planı: türkiye ilaç sektörü 20152018. From www.titck.gov.tr, on 10/04/2018.

W. Roberts, P. (1999). Product innovation, product- market competition and persistent profitability in the U.S. pharmaceutical industry. Strategic Management Journal, 20, 655-670. 